\title{
Student's Satisfaction in Digital Electronic Design Education: A Comparison between Two Education Techniques, Project Based Learning and Micro- Learning
}

\author{
Diaeddin Elmezoghi ${ }^{1}$, Can Doğan Vurdu ${ }^{2}$ \\ ${ }^{1}$ Material Science and Engineering Department, Institute of Science, Kastamonu University, Kastamonu, Turkey \\ ${ }^{2}$ Biomedical Engineering Department, Faculty of Engineering and Architecture, Kastamonu University, Kastamonu, Turkey
}

\begin{abstract}
Measuring student satisfaction is one of the most important methods of assessment and following-up in educational institutions. It is a step to analyze the strengths and weaknesses, develop concepts for the development, identify areas for improvement. and renewal of the learning process and with the develop of the concept of satisfaction from the amount of information that is taught to the students (quantity) to the efficacy of this information (quality) that explore challenges in the real world to the students, generates the need for learning, grows the ability to analyze and solve problem and boost the critical thinking. This paper presents the experience in measuring the satisfaction of students of two education methods applied separately in teaching digital electronic design subject in YuldirımBeyazit University on two groups of students learn the subject in order to find a new effective and instructive learning method, the first group learns the subject using the micro-learning method and the other group learns the subject using a project-based learning method. The use of these methods has had a good impact on student learning and the evaluation of this study shows the difference in applying Micro-learning method in teaching the subject in comparison with applying Project-Based Learning method.
\end{abstract}

Keywords: Student satisfaction, Digital Electronics, Project Based Learning, Micro-learning Introduction, FPGA, Engineering Education

\section{Introduction}

The higher education sector is the main driver of economic growth so that it has become an increasingly competitive market, the satisfaction of university students has become an significant component of quality assurance[1], Assessing students' views and attitudes is a modern necessity as a higher education challenge due to public accountability and increased competition between colleges and universities and for student enrollment[2], and as a measure of college experience and efficacy, student satisfaction is an important indicator for colleges and universities because of it is great impact on motivating students, retaining students, recruiting efforts, and raising funds. As the student's assessment of the quality of the course and other factors related to the curricula and the method of learning is one of the important incentive of student satisfaction, this paper clarified satisfaction factor of two under graduate students groups in digital electronic design learn the subject with the instructive examples and attractive projects covered the course by using Field Programmable Gate Array "FPGA" technology by two different educational technologies, the project based learning technology applied on first group learn the subject and the micro-learning technology applied on the second group. The main goal of study is to meet the growing need to develop educational methods of learning in the university and to improve digital electronic subject education for effective, fast and thorough learning process.

\section{Theoretical Background}

What the Field-Programmable Gate Array (FPGA):
FPGA is a device made of semiconductor material, can be programmed many times to any function, adapted to new standards, even after the product has been installed[3, 4].

FPGA is very adequate than the simple methods we can use to implement any logical function[5,6], because it can cover a very wide range of operating conditions. The free simulator program properties provide great advantage, which make the students attractive at engineering education as well [7]. Currently, in addition FPGAs are commonly used as an education material by many universities in all the world $[8,9]$.

FPGA technology was used in the two groups in teaching the digital electronic design course (the group that applied Micro-learning method and the group that applied ProjectBased Learning method), so that students benefit from the advantages of FPGA technology in applying their examples and in executing their projects and combined various hardware and software activities to make the learning of subject more attractive and beneficial. FPGA features and Graphical Interface with Simulation Software examples are intuitive and powerful tools that promote the interest of students in engineering and science educations, enhance ability to update, and offer advantages to the students for many applications.

The main projects in the study:

1) Factory project

2) Clock project

3) Calendar project

4) CPU project

Volume 7 Issue 10, October 2018 


\section{International Journal of Science and Research (IJSR) \\ ISSN: 2319-7064}

Index Copernicus Value (2016): 79.57 | Impact Factor (2017): 7.296

\subsection{Versions of projects}

The projects arranged in two versions with two levels of complexity.

- Version 1 (V1), it is a class work project it is a simple one; the students should execute this version in the class.

- Version 2 (V2), it is a home work project it is same to V1 in title and function but hard than V1, and it is considered as hard work.

\subsection{The first group Micro-learning model}

Micro-learning is a recent education technique has used only until a two decades and the supporting studies to integrate the technology to form environments of micro-learning is still growing in the higher education field[10].

Micro-learning can be defined as a making a mini courses by series of small and short learning content and small and short activities [11], micro-learning is fiting plan, bite-size the segments of units or activities [12] and prepared to fit the brain limits, with regarding to its attention extent and avoiding cognitive overload, and by other words, microlearning leads researchers to interact with learning on demand for members of our society, such as by increasing the necessity of lifelong learning or by knowledge workers. The education industry is constantly updating the curriculum with the ever-changing industry and the real world to meet the business challenges [13]. in addition, Micro-learning is usually limited, consumed in a short time, sharing resources, depends on interaction between humans and interaction by the media of Internet, takes on a dynamic role in the information filtering and the supplying and it can be emerges from micro features of a variety of ideas and models, offers alternatives and plays a significant role in learning processes based on observation and data gathering[13].

The examples and projects were split into the effective subblocks, Provided in an appropriate manner (internet, electronic media or Small leaflets etc.) throw appropriate means and combine the blocks in the suitable time in the course of Digital Electronic design.

Splitting the examples into the functional (sub-blocks), and locating them to the most appropriate week in the course, forming the modules for each part and making them productive in the education, is taught in the scope of Microlearning method. Micro-learning model is applied in digital electronic course in electric and computer department, second semester students, 2016 fall period (56 student), The students were interactive with this model, the performance and the overall impression were good, completed with good results and it was attractive and instructive.

\subsection{The second group Project-based learning model}

It is an instructive strategy challenges students to think critically[14] and improves their ability to design and execute complex projects[15], improve skill in gathering and assessing the information required to solve problems[16], earn skills[17], working individuals or in groups [18, 19]. and essentially all of these advantages will give students high performance and confidence[20]. Project-based learning, allows students to gain deep knowledge of the ideas and criterions in the project. Projects also build active workplace skills and lifelong behaviors of learning[17]. Projects can allow students to address real-world projects[21], using new technologies, and showing their work. PBL can encourage students who may find school tedious or meaningless. The projects in PBL are the central learning method; students experience and learn the important ideas of the projects, PBL projects are centered around questions or issues that direct students to meet and struggle with the important concepts and principles, provide more independence to the student, choice, unsupervised work time, and responsibility than conventional instructions and conventional projects[22].

In the course PBL offered many choices for students to execute and manage their projects inplanning, designing and in organizing their work in the team or individual. the work in projects achieve the properties of inquiry and innovation, and continually there is a feedback and revision which make learning more meaningful[23, 24].

\section{The Assessment and the Results}

The assessment of the student's satisfaction was based on several questionnaires, covering the academic stages for the subject and the versions of projects. Questions in the questionnaires focused on the extent to which the student benefited from the material and the satisfaction toward each model of the study, the effectiveness and attractiveness of each model and how much it was educational and instructive, and in addition, to what extent do students gain the confidence and ability to design and Smooth handling with elements of digital electronic design. And in accordance to analyzing of the questionnaires the results averages of the comparisons of the models (Micro-Learning ML Model and Project Based Learning PBL)as in the table (1).

Table 1: The average comparison

\begin{tabular}{|c|c|c|}
\hline \multirow{2}{*}{$\begin{array}{c}\text { The models of } \\
\text { the study }\end{array}$} & \multicolumn{2}{|c|}{ Student Satisfaction } \\
\cline { 2 - 3 } & In degree & In $\%$ \\
\hline ML & 3 out of 5 degree & $60 \%$ \\
\hline PBL & 3.6 out of 5 degree & $72 \%$ \\
\hline
\end{tabular}

The Student Satisfaction in applying Micro-Learning (ML) Model was $60 \%$ while the Student Satisfaction in applying Project Based Learning (PBL) Model was 72\% which outbalance the project based learning on micro-learning figure (1)

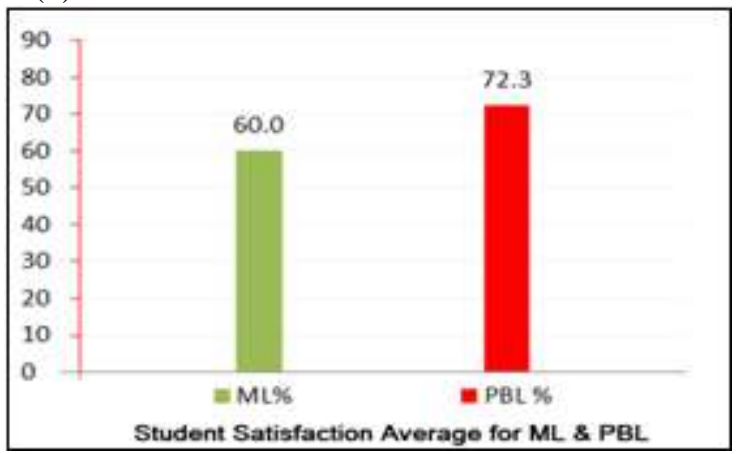

Figure 1: Student satisfaction average for ML Vs PBL

\section{Volume 7 Issue 10, October 2018


International Journal of Science and Research (IJSR)

ISSN: 2319-7064

Index Copernicus Value (2016): 79.57 | Impact Factor (2017): 7.296

Table 2: Independent Samples Test

\begin{tabular}{|c|c|c|c|c|c|c|c|c|c|c|}
\hline \multicolumn{11}{|c|}{ Independent Samples Test } \\
\hline & & \multicolumn{2}{|c|}{$\begin{array}{c}\text { Leweney Tesi sor Equalik } \\
\text { of Variances }\end{array}$} & \multirow[b]{2}{*}{$t$} & \multirow[b]{2}{*}{ at } & \multicolumn{3}{|c|}{ Mest for Equalt of Means } & \multicolumn{2}{|c|}{$\begin{array}{c}955 \text { Confidence interval of the } \\
\text { Difarente }\end{array}$} \\
\hline & & $F$ & sig. & & & (2) talina & Diferente & Ofterunce & Lasar & Unper \\
\hline \multirow[t]{2}{*}{ Satstang } & $\begin{array}{l}\text { Equgr variances } \\
\text { assumpd }\end{array}$ & 3732 & 056 & .3959 & 101 & 001 & .51702 & $183 \pi t$ & 26268 & 98146 \\
\hline & $\begin{array}{l}\text { Equa valiances not } \\
\text { assumpd }\end{array}$ & & & 3,309 & 90.337 & 001 & 61702 & 38648 & 24656 & 98748 \\
\hline
\end{tabular}

Since $\mathrm{p}=.001$ is less than taken significance level $\alpha=0.05$ table (2), we can reject the null hypothesis, and conclude that the mean of student satisfaction for project based learning model and Micro-learning is significantly different and based on the results, we can state the following:

- There was a significant difference in the mean of Student Satisfaction between project based learning model and Micro-learning model $(\mathrm{t} 90.337=3.309, \mathrm{p}<.05)$.

- According to the average of student satisfaction for project based learning model=3.6 degree and the average of student satisfaction for micro-learning=3 degree, the average of student satisfaction for project based learning model was 0.6 degree greater than the average of student satisfaction for micro-learning.

\section{Conclusion}

The objective of this study was to examine the Student Satisfaction in applying two different education techniques (Project Based Learning PBL and Micro-learning). The applying of Micro-learning and Project based learning in digital electronic design subject teaching/slearning was good experience, and the Student Satisfaction when applying Project Based Learning on the subjectin the second group was the best which appears clearly in the results of the questionnaires.

\section{References}

[1] E. H. Thomas and N. Galambos, "What satisfies students? Mining student-opinion data with regression and decision tree analysis," Research in Higher Education, vol. 45, pp. 251-269, 2004.

[2] K. M. Elliott and D. Shin, "Student satisfaction: An alternative approach to assessing this important concept," Journal of Higher Education Policy and Management, vol. 24, pp. 197-209, 2002.

[3] S. Churcher, T. Kean, and B. Wilkie, "The XC6200 FastMap $^{\mathrm{TM}}$ processor interface," in International Workshop on Field Programmable Logic and Applications, 1995, pp. 36-43.

[4] S. D. Brown, R. J. Francis, J. Rose, and Z. G. Vranesic, Field-programmable gate arrays vol. 180: Springer Science \& Business Media, 2012.

[5] S. Hauck, S. Burns, G. Borriello, and C. Ebeling, "An FPGA for implementing asynchronous circuits," IEEE Design and Test of Computers, vol. 11, pp. 60-69, 1994.

[6] S. Hyder, D. Kanth, C. Chandrasekhar, and E. Sammaiah, "Field Programmable Gate Array Implementation Technology," International Journal of Engineering and Advanced Technology, pp. 25-29, 2012.
[7] J. O. Hamblen, "Using second generation SOPC boards for student design projects," in Microelectronic Systems Education, 2005.(MSE'05). Proceedings. 2005 IEEE International Conference on, 2005, pp. 69-70.

[8] V. Kiray, S. Demir, and M. Zhaparov, "Improving Digital Electronics Education with FPGA technology, PBL and Micro Learning methods," in Teaching, Assessment and Learning for Engineering (TALE), 2013 IEEE International Conference on, 2013, pp. 445-448.

[9] A. Kumar, S. Fernando, and R. C. Panicker, "Projectbased learning in embedded systems education using an FPGA platform," IEEE transactions on education, vol. 56, pp. 407-415, 2013.

[10] H. Hierdeis, "From meno to microlearning: A historical survey," Didactics of microlearning. Concepts, discourses and examples, pp. 35-52, 2007.

[11] E. Alqurashi, "Microlearning: A Pedagogical Approach for Technology Integration."

[12] T. Hug, "Micro learning and narration: exploring possibilities of utilization of narrations and storytelling for the design of "micro units" and didactical microlearning arrangements," Proceedings of Media in Transition, 2005.

[13] M. A. Job and H. S. Ogalo, "Micro learning as innovative process of knowledge strategy," International journal of scientific \& technology research, vol. 1, pp. 92-96, 2012.

[14] J. Bradley-Levine and G. Mosier, "Literature review on project-based learning," University of Indianapolis Center of Excellence in Leadership of Learning, 2014.

[15] F. Machado, S. Borromeo, and N. Malpica, "Project based learning experience in VHDL digital electronic circuit design," in Microelectronic Systems Education, 2009. MSE'09. IEEE International Conference on, 2009, pp. 49-52.

[16] B. F. Jones, C. M. Rasmussen, and M. C. Moffitt, Real-life problem solving: A collaborative approach to interdisciplinary learning: American Psychological Association, 1997.

[17] J. Strobel and A. Van Barneveld, "When is PBL more effective? A meta-synthesis of meta-analyses comparing PBL to conventional classrooms," Interdisciplinary Journal of Problem-based Learning, vol. 3, p. 4, 2009.

[18] J. W. Thomas, Project based learning: A handbook for middle and high school teachers: Buck Institute for Education, 1999.

[19] J. Ravitz, "Project Based Learning as a Catalyst in Reforming High Schools," Buck Institute for Education, 2008.

[20] V. Elmezoghi, "Student's Performance in Digital Electronic Design: A Comparison Between Two Education Techniques, Project Based Learning and 


\section{International Journal of Science and Research (IJSR) \\ ISSN: 2319-7064}

Index Copernicus Value (2016): 79.57 | Impact Factor (2017): 7.296

Micro-learning," International Journal of Science and Research (IJSR), vol. 7, 2018.

[21] P. C. Blumenfeld, E. Soloway, R. W. Marx, J. S. Krajcik, M. Guzdial, and A. Palincsar, "Motivating project-based learning: Sustaining the doing, supporting the learning," Educational psychologist, vol. 26, pp. 369-398, 1991.

[22] F. Musa, N. Mufti, R. A. Latiff, and M. M. Amin, "Project-based learning: Promoting meaningful language learning for workplace skills," ProcediaSocial and Behavioral Sciences, vol. 18, pp. 187-195, 2011.

[23] J. Larmer and J. R. Mergendoller, "Seven essentials for project-based learning," Educational leadership, vol. 68, pp. 34-37, 2010.

[24] J. L. Polman, Designing Project-Based Science: Connecting Learners through Guided Inquiry. Ways of Knowing in Science Series: ERIC, 2000.

Volume 7 Issue 10, October 2018

www.ijsr.net 